\section{Canine visceral leishmaniasis in the Krenak indigenous community, Resplendor, Minas Gerais State, Brazil, 2007}

\author{
Leishmaniose visceral canina na Terra Indígena \\ Krenak, Resplendor, Minas Gerais, Brasil, 2007
}

\author{
Eloiza Gonçalves Antônio 1,2 \\ Marcos Aurélio Fulgêncio Malacco ${ }^{3}$ \\ Célia Maria Ferreira Gontijo 2 \\ Eliana Furtado Moreira 4 \\ Ivo Santana Caldas 5 \\ João Luiz Pena 6 \\ George Luiz Lins Machado-Coelho 7
}

\section{Abstract}

1 Universidade Vale do Rio Doce, Governador Valadares, Brasil.

2 Centro de Pesquisas René Rachou, Fundação Oswaldo Cruz, Belo Horizonte, Brasil. 3 Fundação Nacional de

Saúde, Belo Horizonte, Brasil.

${ }^{4}$ Instituto Octávio

Magalhães, Fundação

Ezequiel Dias, Belo

Horizonte, Brasil.

${ }^{5}$ Núcleo de Pesquisa

em Ciências Biológicas,

Universidade Federal de Ouro

Preto, Ouro Preto, Brasil.

${ }^{6}$ Escola de Engenharia,

Universidade Federal de

Minas Gerais, Belo Horizonte, Brasil.

7 Departamento de Ciências

Médicas, Universidade

Federal de Ouro Preto, Ouro

Preto, Brasil.

Correspondence

E. G. Antônio

Laboratório de Leishmanioses,

Centro de Pesquisas René

Rachou, Fundação Oswaldo

Cruz.

Rua Augusto de Lima 1715,

Belo Horizonte, $M G$

30190-002, Brasil.

eloiza_ga@hotmail.com unknown. Indians
The authors conducted a cross-sectional study of the local canine population in the Krenak indigenous community to detect parasites of the genus Leishmania and identify the circulating species and the proportion of asymptomatic dogs, while investigating associations between canine infection and the dogs' sex, age, and hair length. A seroepidemiological survey was performed, including 63 dogs. All the animals underwent clinical examination to verify the presence of characteristic signs, and serum samples were taken for serological tests (ELISA, IIF). Infected dogs culled by the health service were necropsied and the material was analyzed using molecular diagnostic techniques. The cross-sectional study detected a $46 \%$ prevalence rate, and the circulating species was Leishmania (L.) chagasi. The statistical analysis showed no association between infection and the independent variables. The study generated data on the epidemiological situation with canine infection in the area, which was previously

Visceral Leishmaniasis; Dogs; South American

\section{Introduction}

American visceral leishmaniasis (AVL) is caused by caused by parasites of the genus Leishmania and transmitted by phlebotomine sandflies 1,2 , 3,4 . Reservoirs for the disease include the domestic dog, of major epidemiological importance in maintaining the disease cycle. Various studies $3,5,6$ have shown that in some cases canine infection precedes the appearance of human cases, but this finding may reflect dogs' greater susceptibility to the infection. Culling of infected dogs as a prophylactic and control measure is routine in endemic control programs 7,8. Serological diagnosis may not detect asymptomatic infections 9. Molecular tests appear promising, but their precision and reproducibility are still under investigation 10,11.

This cross-sectional study was performed to generate epidemiological data on the presence of canine infection, its etiology, and dogs' susceptibility to the infection. The study area was classified as susceptible to visceral leishmaniasis, based on detection of the vector Lutzomyia longipalpis in 2007 by the Minas Gerais State Health Department (SES/MG).

\section{Material and methods}

The Krenak indigenous community is located in the municipality (county) of Resplendor, Minas 
Gerais State, Brazil. The municipality has a total population of 17,124 , of whom 300 are Krenak indigenous people belonging to 60 families. The indigenous community consists of three villages: Barra do Eme, Cacique, and Porto da Barca. During the survey, 63 dogs from all three villages in the Krenak indigenous community were examined and tested, representing $94 \%$ of the total estimated canine population of 67 animals. A canine seroepidemiological survey was performed, a routine practice under the Endemics Control Sector of the National Health Foundation (FUNASA), the institution responsible for taking serum and tissue samples and culling the infected dogs. The study and procedures dispensed with prior approval by ethics committees.

The dogs were classified as follows: asymptomatic (absence of signs), symptomatic (more than three signs), and oligosymptomatic (one to two signs). A questionnaire was prepared by the René Rachou Research Center of the Oswaldo Cruz Foundation (CPqRR/Fiocruz) and applied by the veterinarian in charge of the survey.

The target signs were: wasting, opaque hair and cornea, keratoconjunctivitis, hepatomegaly, splenomegaly, onychogryphosis, paw edema, alopecia, ulcers, furfuraceous dermatitis, limb paresis, blindness, and lymphadenopathy. Other data collected were sex, age, hair length, and breed.

The serological tests were ELISA for screening and indirect immunofluorescence (IIF) as the confirmatory test. The antigens were provided by the Institute of Immunobiological Technology of the Oswaldo Cruz Foundation (Bio-Manguinhos/Fiocruz).

Serological testing was performed by the Ezequiel Dias Foundation (FUNED) in parallel with the Federal University in Ouro Preto (UFOP).

The infected animals were sacrificed by a veterinarian. After verification of the animal's sedation with xylazine chlorhydrate reinforced with thiopental, euthanasia was performed by electrical shock. Disposal of the cadavers of the euthanized dogs complied with Ruling RDC $n^{\circ}$. 33 of February 25, 2003 12. The tissue samples were sent to CPqRR/Fiocruz for identification of the circulating species of Leishmania spp. The molecular method used was polymerase chain reaction (PCR) 13. Species identification used RFLP-PCR 14.

Prevalence rates were compared according to sex, age, and hair length using the chi-square test with $95 \%$ significance $(\mathrm{p}<0.05)$.

\section{Results}

Prevalence of canine infection was $40 \%$ in the Barra do Eme village, 35\% in the Cacique village, and $76.9 \%$ in the Porto da Barca village, with an overall rate of $46 \%$ (Table 1). No statistical difference was observed between occurrence of the infection and the variables sex, age, or hair length (Table 2).

According to the clinical classification, $27.3 \%$ of the dogs were asymptomatic, $54.5 \%$ oligosymptomatic, and $18.2 \%$ symptomatic. The most frequent symptoms were: splenomegaly, wasting, onychogryphosis, opaque fur, and hepatomegaly. Some typical symptoms of canine visceral leishmaniasis like alopecia, furfuraceous dermatitis, and keratoconjunctivitis were less frequent. The circulating species was Leishmania (Leishmania) chagasi.

\section{Discussion}

Although overall prevalence was $46 \%$, distribution of cases by village was heterogeneous, with $76.9 \%$ prevalence in Porto da Barca, $40 \%$ in Barra do Eme, and 35\% in Cacique.

Even without previous reporting of human or canine cases, canine surveys are important for monitoring the disease in the Krenak indigenous community. Indigenous peoples in Brazil are generally subject to precarious living and health conditions. The indigenous communities lack basic sanitation and have high malnutrition and parasite infection rates, besides other diseases 15.

Canine reservoirs play a central role in the expansion of the visceral leishmaniasis in endemic areas $16,17,18,19$.

There was a high prevalence of asymptomatic dogs. One hypothesis that could explain the ineffectiveness of culling infected dogs as a control measure is the persistence of undetected asymptomatic animals due to the diagnostic tests' low sensitivity, so that these dogs remain in the area and contribute to maintenance of the disease $19,20,21$.

Contrary to our findings in the Krenak indigenous community, various authors have shown a positive correlation between canine visceral leishmaniasis and variables like sex 22,23,24, age 25 , and hair length 26 . Meanwhile, other authors have failed to show a correlation between canine visceral leishmaniasis and any variables related to the animals. These differences between various authors' findings could be due in part to the use of different methodologies to estimate the prevalence of canine visceral leishmaniasis 27,28 . 
We emphasize the importance of frequent serological surveys and knowledge of the relative abundance of the various Lutzomyia species, aimed at identifying the most susceptible period for visceral leishmaniasis transmission and orienting chemical vector control measures.

\section{Conclusions}

In order to better understand the epidemiology of canine visceral leishmaniasis and avoid the emergence of human cases in the Krenak indigenous community, regular serological surveys are needed, followed by culling of infected dogs and studies on sandfly density.

Table 1

Canine seroepidemiological survey for canine visceral leishmaniasis in the Krenak indigenous community. Resplendor, Minas Gerais State, Brazil, 2007.

\begin{tabular}{llcccccc}
\hline Village & \multicolumn{2}{c}{ Indeterminate } & \multicolumn{2}{c}{ Negative } & \multicolumn{2}{c}{ Positive } & Prevalence (\%) \\
& $\mathbf{n}$ & $\%$ & $\mathbf{n}$ & $\%$ & $\mathbf{n}$ & $\%$ \\
\hline Barra do Eme & 6 & 50.0 & 12 & 54.5 & 12 & 41.4 & 40.0 \\
Cacique & 3 & 25.0 & 10 & 45.5 & 7 & 24.1 & 35.0 \\
Porto da Barca & 3 & 25.0 & 0 & 0.0 & 10 & 34.5 & 76.9 \\
Total & 12 & 100.0 & 22 & 100.0 & 29 & 100.0 & 46.0 \\
\hline
\end{tabular}

Table 2

Canine visceral leishmaniasis prevalence rate according to sex, age, and hair length of dogs tested in the Krenak indigenous community. Resplendor, Minas Gerais State, Brazil, 2007.

\begin{tabular}{|c|c|c|c|c|c|c|}
\hline Variables & $\begin{array}{c}\text { Relative } \\
\text { distribution (\%) }\end{array}$ & $\begin{array}{c}\text { Dogs } \\
\text { examined }\end{array}$ & Prevalence (\%) & Reactive dogs & $95 \% \mathrm{Cl}$ & p-value \\
\hline \multicolumn{7}{|l|}{ Sex } \\
\hline Male & 40.3 & 26 & 50.0 & 13 & $26.4-63.4$ & 0.59 \\
\hline Female & 59.7 & 37 & 43.2 & 16 & $35.7-73.6$ & \\
\hline \multicolumn{7}{|l|}{ Age (years) } \\
\hline $0.0-\mid 3.0$ & 77.7 & 49 & 40.8 & 20 & & 0.12 \\
\hline $3.0-16.0$ & 22.3 & 14 & 64.3 & 9 & & \\
\hline \multicolumn{7}{|l|}{ Hair } \\
\hline Shorthair & 93.6 & 59 & 44.0 & 26 & $76.3-98.1$ & 0.40 \\
\hline Longhair & 6.4 & 4 & 75.0 & 3 & $1.9-23.7$ & \\
\hline Total & 100.0 & 63 & 46.0 & 29 & $41.7-67.5$ & \\
\hline
\end{tabular}

95\% Cl: 95\% confidence interval.

Note: $p>0.05$ (non-significant). 


\section{Resumo}

Foi realizado um estudo seccional para detectar, na população canina, a presença de parasitos do gênero Leishmania e a espécie circulante, a proporção de cães assintomáticos, investigando concomitantemente a existência de associações entre a infecção canina e as variáveis: sexo, idade e tipo de pelo dos cães. Para o estudo seccional, foi realizado um inquérito censitário, que avaliou 63 cães. Todos passaram por uma avaliação clínica para verificar a presença de sintomas característicos da infecção; amostras de soro foram coletadas para os testes sorológicos (ELISA, RIFI). Os cães positivos retirados pelo serviço de saúde foram necropsiados, e o material, analisado pelas técnicas de diagnóstico molecular. O estudo seccional realizado detectou uma prevalência de 46\%, sendo a espécie circulante $a$ Leishmania (L.) chagasi. A análise estatística não detectou nenhuma associação entre infecção $e$ as variáveis investigadas. Este estudo possibilitou a geração de dados sobre a situação epidemiológica da infecção canina na área, o que antes era desconhecido.

Leishmaniose Visceral; Cães; Índios Sul-Americanos

\section{Contributors}

E. G. Antônio participated in the data collection, sample processing, statistical analysis, and writing of the article. M. A. F. Malacco coordinated the field activities and participated in the georeferencing, data collection, and writing of the article. C. M. F. Gontijo participated in the molecular testing and revised the article. E. F. Moreira conducted the serological testing and revised the article. I. S. Caldas participated in the serological testing and revised the article. J. L. Pena participated in the study design and revised the article. G. L. L. MachadoCoelho participated in the study design and epidemiological analysis and revised the article.

\section{Acknowledgments}

The authors wish to thank the Brazilian National Health Foundation for the logistic support, the Ezequiel Dias Foundation and the Federal University in Ouro Preto for the serological testing, and the René Rachou Research Center/Fiocruz for the molecular testing.

\section{References}

1. Lainson R, Rangel, EF. Lutzomyia longipalpis and the eco-epidemiology of American visceral leishmaniasis, with particular reference to Brazil - a review. Mem Inst Oswaldo Cruz 2005; 100:811-27.

2. Desjeux, $\mathrm{P}$. The increase in risk factors for leishmaniasis worldwide. Trans R Soc Trop Med Hyg 2001; 95:239-43

3. Marzochi MCA, Coutinho SG, Souza WJS, de Toledo LM, Grimaldi Jr. G, Momen H, et al. Canine visceral leishmaniasis in Rio de Janeiro, Brazil. Clinical, parasitological, therapeutical and epidemiological findings (1977-1983). Mem Inst Oswaldo Cruz 1985; 80:349-57.

4. Baneth G, Koutinas AF, Solano-Galleno L, Bourdeau P, Ferrer L. Canine leishmaniosis - new concepts and insights on an expanding zoonosis: part one. Trends Parasitol 2008; 24:324-30.

5. Mattos Jr. DG, Pinheiro JM, Menezes RC, Costa DA. Aspectos clínicos e de laboratório de cães soropositivos para leishmaniose. Arq Bras Med Vet Zootec 2004; 56:119-22.
6. Santa Rosa ICA, Oliveira ICS. Leishmaniose visceral: breve revisão sobre uma zoonose reemergente. Clínica Veterinária 1997; 2:24-8.

7. Quinnell RJ, Courtenay O. Transmission, reservoir hosts and control of zoonotic visceral leishmaniasis. Parasitology 2009; 136:1915-34.

8. Departamento de Vigilância Epidemiológica, Secretaria de Vigilância em Saúde, Ministério da Saúde. Manual de vigilância e controle da leishmaniose visceral. Brasília: Editora do Ministério da Saúde; 2006. (Série A. Normas e Manuais Técnicos).

9. Krauspenhar C, Beck C, Sperotto V, Silva AA, Bastos $R$, Rodrigues L. Leishmaniose visceral em um canino de Cruz Alta, Rio Grande do sul, Brasil. Ciênc Rural 2007; 37:907-10.

10. Evans TG, Vasconcelos IAB, Lima JB, Teixeira JM, McAuliffe IT, Lopes UG, et al. Canine visceral leishmaniasis in northeast Brazil: assessment of serodiagnosis methods. Am J Trop Med Hyg 1990; 42: 118-23. 
11. Romero GA, Boelaert M. Control of visceral leishmaniasis in Latin America: a systematic review. PLoS Negl Trop Dis 2010; 4:e584.

12. Agência Nacional de Vigilância Sanitária. Resolução RDC nº. 33, de 25 de fevereiro de 2003. Diário Oficial da União 2003; 5 mar.

13. Degrave W, Fernandes O, Campbell D, Bozza M, Lopes U. Use of molecular probes and PCR for detection and typing of Leishmania: a mini-review. Mem Inst Oswaldo Cruz 1994; 89:463-9.

14. Volpini AC, Passos VMA, Oliveira GC, et al. PCRRFLP to identify Leishmania (Viannia) brasiliensis and L. (Leishmania) amazonensis causing American cutaneous leishmaniasis. Acta Trop 2004; 90:31-7.

15. Pena JL. Perfil sanitário, indicadores demográficos e saúde ambiental após a implantação do Distrito Sanitário Especial Indígena: o caso dos Xakriabá em Minas Gerais [Dissertação de Mestrado]. Belo Horizonte: Universidade Federal de Minas Gerais; 2004.

16. Nunes VL, Galati EA, Nunes DB, Zinezzi RO, Savani ES, Ishikawa E, et al. Occurrence of canine visceral leishmaniasis in an agricultural settlement in the State of Mato Grosso do Sul, Brazil. Rev Soc Bras Med Trop 2001; 34:299-300.

17. Deane MP, Deane LM. Infecção experimental do Phlebotomus longipalpis em raposa (Lycalopex vetulus) naturalmente parasitada por pela Leishmania donovani. O Hospital 1954; 46:651-3.

18. Santos SO, Arias JR, Ribeiro AA, de Paiva Hoffmann M, de Freitas RA, Malacco MA. Incrimination of Lutzomyia cruzi as a vector of American visceral leishmaniasis. Med Vet Entomol 1998; (12):315-7.

19. Molina R, Amela C, Nieto J, San-Andrés M, González F, Castilho JA, et al. Infectivity of dogs naturally infected with Leishmania infantum to colonized Phlebotomus perniciosus. Trans R Soc Trop Med Hyg 1994; 88:491-3.

20. Senra MS, Pimentel PSR, Souza PEFP. Leishmaniose visceral em Santarém, Pará. Aspectos gerais do controle. Inquérito sorológico de cães e tratamento dos casos humanos. Hiléia Méd 1986; (7):23-32.
21. Luvizotto MCR, Ferrari HF, Moreira MAB. Lesão nodular na cavidade oral de cão causada por Leishmania sp. - relato de casos. Arq Bras Med Vet Zootec 2005; 57:18-9.

22. França-Silva JC, Barata RA, Costa RT, Monteiro EM, Machado-Coelho GL, Vieira EP, et al. Importance of Lutzomyia longipalpis in the dynamics of transmission of canine visceral leishmaniasis in the endemic area of Porteirinha Municipality, Minas Gerais, Brazil. Vet Parasitol 2005; 10:213-20.

23. Alencar JE, Cunha RV. Inquéritos sobre calazar canino no Ceará; novos resultados. Rev Bras Malariol Doenças Trop 1963; 15:391-403.

24. Lanotte G, Rioux JA, Crosset, H, Vollhardt Y. Écologie des leishmanioses dans le Sud de la France. VIII. Complément à l'application epidémiologique de la technique d'immunofluorescence: les titres geometrices et arithmetiques mohines dans la leishmaniose canine. Ann Parasitol Hum Comp 1975; 50:1-5.

25. Feitosa MM. Avaliação clínica de animais naturalmente infectados. In: Anais do Primeiro Fórum sobre Leishmaniose Visceral Canina. Jaboticabal: Faculdade de Ciências Agrárias e Veterinárias, Universidade Estadual Paulista; 2006. p. 6-9.

25. Borges APB. Composição do líquido sinovial de cães com ruptura do ligamento cruzado cranial. Ciênc Rural 1999; 29:285-9.

26. Quinnell RJ, Courtenay O, Davidson S, Garcez L, Lambson B, Ramos P, et al. Detection of Leishmania infantum by PCR, serology and immune response in a cohort study of Brazilian dogs. Parasitology 2001; 122:253-61.

27. Reithinger R, Quinnell RJ, Alexander B, Davies CR. Rapid detection of Leishmania infantum infection in dogs: comparative study using an immunochromatographic dipstick test, enzyme-linked immunosorbent assay, and PCR. J Clin Microbiol 2002; (40):2352-6.

Submitted on 22/Dec/2009

Final version resubmitted on 02/Sep/2010

Approved on 10/Sep/2010 